\title{
Frederic Duval, Une nouvelle traduction de l"Historia de duobus amantibus, Eurialus et Lucretia'd'Aeneas Sylvius Piccolomini
}

\section{Gianni Mombello}

\section{(2) OpenEdition Journals}

Édition électronique

URL : http://journals.openedition.org/studifrancesi/35803

DOI : 10.4000/studifrancesi.35803

ISSN : 2421-5856

Éditeur

Rosenberg \& Sellier

\section{Édition imprimée}

Date de publication : 1 juillet 2005

Pagination : 140

ISSN : 0039-2944

\section{Référence électronique}

Gianni Mombello, "Frederic Duval, Une nouvelle traduction de I"Historia de duobus amantibus, Eurialus et Lucretia'd'Aeneas Sylvius Piccolomini », Studi Francesi [En ligne], 145 (XLIX | I) | 2005, mis en ligne le 30 novembre 2015, consulté le 18 avril 2021. URL : http://journals.openedition.org/studifrancesi/35803 ; DOI : https://doi.org/10.4000/studifrancesi.35803 
Frederic Duval, Une nouvelle traduction de l'Historia de duobus amantibus, Eurialus et Lucretia'd'Aeneas Sylvius Piccolomini

Gianni Mombello 


\section{RÉFÉRENCE}

FREDERIC DUVAL, Une nouvelle traduction de l'Historia de duobus amantibus, Eurialus et Lucretia'd'Aeneas Sylvius Piccolomini, «Romania», 121, 3-4, 2003, pp. 538-43.

1 Aux deux traductions françaises connues de l'Historia de duobus amantibus d'Enea Silvio Piccolomini composée en 1444, dont l'une est d'Octovien de Saint-Gelais et l'autre d'Antitus Faure, il faut maintenant en ajouter une troisième anonyme conservée dans le ms. fr. 19178 de la BNF. Elle aussi pourrait remonter à la fin du XV $\mathrm{XV}^{\mathrm{e}}$ siècle, mais cela n'est pas sûr.

2 Cette nouvelle traduction n'est pas fondée sur le texte de Piccolomini mais sur le deuxième remaniement de l'Historia qu'Alessandro Braccesi avait exécuté, entre 1481 et 1483, après un premier des années 1478-1479.

3 La langue du traducteur est hybride et excessivement proche de celle de l'original. On peut supposer que ce traducteur était un italien. Sa date reste très hypothétique (1481-83 -1531). Cet article fournit aussi une autre précision intéressante. La date de la traduction de l'Historia par Octovien de Saint-Gelais doit être avancée de quelques années (1488-1489) par rapport à l'édition Vérard (1493), puisqu'elle est mentionnée dans l'Estrif de Science, Nature et Fortune, traduction française d'un traité allégorique de Jacques de Saint-Gelais, achevé le 20 août 1488, et que son frère Octovien avait aussitôt mis en français. 